Halina Twaranowicz

Uniwersytet w Białymstoku

Wydział Filologiczny

Kolegium Literaturoznawstwa

tel.: +48 696175022

e-mail: h.twaranowicz@uwb.edu.pl

ORCID ID: https://orcid.org/0000-0002-6895-9010

\title{
Диариуш Афанасия Филипповича и Житие протопопа Аввакума: типологические схождения в историческом контексте
}

Ключевые слова: полемическая литература, агиография, автобиографизм, пафос произведений, духовный потенциал, Брестская уния, старообрядческое движение

На очевидную типологическую общность Диариуша Афанасия Филипповича (1597-1648) и «Жиития протопопа Аввакума (1621-1682) некоторые белорусские исследователи обратили внимание уже в конце 60-х годов прошлого столетия. Так, П.П. Ахрименко и М.Р. Ларченко констатировали, что обоим произведениям свойствен публицистический пафос непрымірымасці да праиіўнікаў, а также сходство определенных композиционно-стилевых приемов: выкарыстанне містыиных «відзенняуั», арьентаиьля на жьвую мову народа, на вусную народную творчасць $і$ інш. [Ахрыменка, Ларчанка 1968, 109]. Совершенно справедливо отмечалось, что эта общность Диариуша и Жития обусловлена эмоциональным сходством авторов па тэмпераменту $i$ мужнасиі, па страснасці і прынцыповай паслядоўнасці, па рашучай смеласиі $і$ непахіснай стойкасці ў змаганні за свае ідэі (...) [Ахрыменка, Ларчанка 1968, 109].

Следует подчеркнуть, что писательский потенциал Афанасия Филипповича и протопопа Аввакума оказался востребованным в трагических обстоятельствах их последовательного отстаивания своих убеждений всеми возможными, доступными им средствами. Афанасий Филип- 
пович пишет значительную часть своего Диариуша, находясь в Варшавской тюрьме, а потом заключенный под арест в келье Киево-Печерского монастыря. Протопоп Аввакум создает свое Житие во время заточения на Крайнем Севере в Пустозерске в земляном срубе. Перед лицом неизбежного конца до последнего дыхания оба остаются непреклонными в отстаивании своей незыблемой правоты, сознательно приняв за это мученическую смерть: Афанасий Филиппович после жестоких истязаний был расстрелян 15 сентября 1648 года недалеко от Бреста, а протопоп Аввакум и трое его единомышленников были сожжены 14 апреля 1682 года в Пустозерске.

Вскоре после смерти Афанасий Филиппович был канонизирован церковью. В житии на польском языке, составленном в 1666 году в Бресте, игумен Симяоновского монастыря Афанасий назывался «святым и преподобномучеником». Надо отметить, что трагическую судьбу будущего святого прежде всего определило церковное событие, произошедшее совсем незадолго до его рождения на родной ему Брестчине, с которой связана значительная часть жизни Афанасия Филипповича.

В 1596 году на церковном соборе в Бресте был принят акт об организационном объединении католической и православной церквей на территории Речи Посполитой. Объединение проводилось на основе взаимных уступок: признавалось главенство папы римского, в церковных догматах нисхождение Святого Духа не только от Бога-Отца, но и от Бога-Сына (католический догмат); при этом сохранялись все православные обряды, богослужения и проповеди на церковнославянском языке. Среди причин принятия Брестской унии называются стремление иерархии местной православной церкви (во главе с киевским митрополитом) быть независимой от константинопольского патриарха, который в свою очередь зависел после захвата турками в 1453 году Константинополя от турецкого султана, а также нежелание подчиняться московскому патриарху, который был возведен в 1589 году в этот сан из сана митрополита и больше не подчинялся патриарху константинопольскому, называясь патриархом «всея Руси», имея намерение распространить свое влияние и на православную церковь Беларуси и Украины. Кроме того православные иерархи рассчитывали получить места в сенате Речи Посполитой наравне с католическими епископами, чем, по их мнению, был бы ликвидирован кризис православной церкви, который обострился в конце XVI века. Римско-католическая церковь и кароль Речи Посполитой Жигимонт III Ваза видели в унии возможность для идейного единства духовенства и феодалов Ве- 
ликого Княжества Литовского при проведении внутренней и внешней политики правящих кругов Речи Посполитой, а также средство для совместной борьбы против Реформации.

Инициаторами заключения Брестской унии были верхи православной церкви в Речи Посполитой: митраполит киевский, галицкий и всея Руси М. Рагоза, епископ владимерский и берестейский И. Патей, патриарший экзарх епископ луцкий и астрожский К. Терлецкий, полоцкий и витебский епископ Р. Храптович и др. Против заключения унии выступили книязь К. Астрожский, епископы галицкий и каменец-подольский Г. Балабан, перемышльский и самборский М. Капыстенский, часть духовенства и горожан. Таким образом, собор, на котором утверждалась уния, оказался поделенным на две противоположные группировки, которые собирались отдельно. Девятого октября 1596 года в церкви св. Николая была торжественно провозглашена Брестская уния и церковь стала называться грецко-католической. Православный собор в свою очередь унию не принял [Грыцкевіч 1994, 2/98; Падокшын 2000].

Явившись продолжением Флорентийской унии 1438-1439 годов, когда киевский митрополит Исидор от имени всей русской православной церкви дал согласие на объединение ее с католической, Бресткая уния должна была компенсировать отсутствие ожидаемых результатов. Ближайшей ее целью изначально был перевод православного населения Беларуси и Украины в греко-католическое вероисповедание, осуществляемый ввиду активного сопротивления населения чрезвычайно жестокими средствами. Так, повсеместно у православных силой отымались церкви, запрещались богослужения не только в храме, но и люто преследовалось тайное проведение обрядов крещения, отпевания на дому, даже в лесах.

Сохранилась переписка между известным униятским иерархом Иосафатом Кунцевичем, особенно активно прививавшим униатство, и канцлером Великого Княжества Литовского Львом Сапегой. Вера $\ddot{е ̈ с и ь ~ д а р ~ Б о ж ь l, ~-~ ч е т к о ~ ф о р м у л и р у е т ~ с в о и ~ у б е ж д е н и я ~ И . ~ К у н ц е в и ч, ~}$ при этом подчеркивая, - але каталічкая, не схізматычная $i$ не ератычная, бо прызнаючы за адшчапенскай верай тое, што яна дар Божы, вымушаныя будзем прызначь, што блюзнерства любой веры ёсць дар Божьи [Кунцевич 2003, 666]. И далее иерарх продолжает: Магілёўчам иэрквы даўно адчынены, хай у іх Пану Богу і молячиа, маючь святарой - добрых каталікоў, асобнае ж иарквы дзеля іх схізматычнага блюзнерства саступічь з-пад улады маёй не магу; нават калі б мне загадаў найвышэйшы Пастыр Папа Рылскі альбо ягоны легат, 
а інакш быу бы я вінаваты перад Богам і маім каталічкім сумленнем [Кунцевич 2003, 666].

В свою очередь Л. Сапега, сам католик, выполняющий волю короля-католика, глубоко возмущенный жестокими насильственными действиями И. Кунцевича, 12 марта 1622 года пишет ему:

Вы ж гэтак неаглядным стараннем падштурхнулі, можна сказаць, змусілі народ рускі разлютавацца і адвергнуць прынесеную яго Каралеўская Вялікасці прысягу. Цяжка вам тое аспрэчыць, калі абвінавачваюць вас у гэтым пададзеныя ад іх урадоўцам польскім і Вялікага Княства Літоўскага пісьмовыя скаргі. Ці ж не вядомыя вам нараканні непазважлівага народа i ix абвяшчэнне, што яны жадаюць быць лепш у турэцкім падданстве, як зносіць гэткі веры й дабрадзейнасці іхняй уціск? (...) Замест радасці прычыніла нам ваша квапная Унія жальбы, клопаты і неўладкаванасці, і настолькі [яна] вартая смутку, што лепш для нас было б жыць без яе; з-за яе зносім мы заўсёдныя клопаты, смутак і прыкрасці. Вось плён вашай хвалёнай Уніi! Дастатковая па ісціне, яна вінаватая у столькіх у людзях і ў Айчыне разладах і неўладкаванасцях! Бо, барані Божа, калі Айчына уззрушыцца, да чаго вы праз сваю суровасць гэткі зручны адчыняеце шлях, - не ведаю, што ў той час в вашай Уніяй будзе [Сапега 2003, 668-672].

Брестская уния 1596 года стимулировала оживление в Великом Княжестве Литовском церковно-религиозной и социально-политической полемической публицистики, возникшей в свое время как результат столкновения на восточнославянской почве миссионеров православного и католического вероисповедания. Полемическая литература Беларуси 90-х годов XVI - первой половины XVII века представляет собой, как справедливо отмечает Иван Саверченко, уникальное явление художественно-эстетической и духовной культуры. Выделяясь богатством жанров, литературных форм, степенью влияния на важнейшие сферы жизни общества, она относится к основным видам художественного слова эпохи барокко [Саверчанка 2007, 500]. Наиболее яркими представителями белорусской полемической литературы были Христофор Филалет, Стефан и Лаврентий Зизании, Ипатий Патей, Мелетий Смотрицкий, Андрей Мужиловский, Язеп Вельямин Руцкий, Сильвестр Косов. На последнем этапе развития полемической публицистики как наиболее значительный ее автор присоединился к борьбе против церковной унии Афанасий Филиппович.

Жизненные обстоятельства и характер творческого наследия протопопа Аввакума, как и автора Диариуша, также главным образом предопределило событие церковного характера, вошедшее в историю как «раскол» в русской жизни второй половины XVII века и обу- 
словившее возникновение религиозно-общественного движения старообрядчества.

В 1651 году по почину новоизбранного патриарха Никона, с одобрения царя Алексея Михайловича, в русской церкви с целью приведения к единству русского церковного обряда и богослужебных книг с греческой церковной практикой были произведены некоторые реформы в сфере религиозной обрядности и исправления богослужебных текстов. Реформа была в значительной мере обусловлена началом реализации теории «Москвы - третьего Рима», согласно которой Москва являлась преемницей Рима и Константинополя и должна была освободить от турецкого ига всех порабощенных христиан Востока. Эта идея поддерживалась и восточными патриархами - иерусалимским Паисием, а также бывшим константинопольским патриархом Афанасием Бателеаром, которые состояли в переписке с царем Алексеем Михайловичем, считавшим себя преемником византийских императоров. Однако для того, чтобы московский царь мог успешно распространить свою власть и на восточных христиан, нужно было устранить моменты, разъединяющие русскую и византийскую церкви, что прежде всего касалось некоторых несовпадений в богослужебных обрядах. При том следует отметить, что эти различия никоим образом не свидетельствовали об искажении русскими принятой первоначально обрядности, а явились следствием того, что во время крещения Руси в 988 году в Византии существовали различные богослужебные уставы. На Русь перешел так называемый студийский устав, принятый тогда в Константинополе. Однако с XI века в Византии все больше стал распространяться устав иерусалимский, закрепившийся к началу XIV века повсеместно в стране. На протяжении трех столетий происходило также и постепенное изменение в греческих богослужебных книгах, так что русский вариант, соответствующий константинопольским текстам X-XI веков, воспринимался греками уже с XIV века как «неисправный», «испорченный».

Очевидно, ни патриарх Никон, ни царь не могли предположить, к какому драматическому общественному резонансу приведет их церковная реформа. Оппозиционное отношение к нововведениям выразило прежде всего среднее и низкое духовенство, отражавшее по существу социальный протест закрепощенного крестьянства и жестоко эксплуатируемого посада - городской буржуазии. Для этих социальных слоев, отягощенных тяжелыми государственными и церковными поборами, возросшими с введением на патриарший престол Никона, защита «старой веры» была выражением и борьбы против угнетения, 
социальной несправедливости. Реформа воспринималась ее противниками, по словам Н. К. Гудзия, и как очередное унижение, как посягательство на святое святых:

Сила и спасительность старого обряда были проверены и подтверждены в их глазах тем, что русские святые, прославившие русскую церковь, угодили богу, общаясь с ним именно по этому самому старому обряду, теперь гонимому и попираемому. Признать неправильность этого обряда или усомниться в нем для защитников старины значило бы усомниться в святости подвижников, украсивших Русскую землю. Новый обряд шел из Греции, той самой Греции, которая еще два века назад за отступление от «истинного» благочестия, как утверждала традиционная мысль, была покарана богом, отдавшим ее во власть неверных. Два века официальная церковная публицистика учила тому, что подлинной и единственной хранительницей православного благочестия является только русская церковь, которая теперь должна была признать высший авторитет церкви греческой. Поскольку, далее, церковная реформа была связана с иноземной традицией, она, не будучи ни в какой мере продуктом западного влияния, a, наоборот, будучи вызвана к жизни охранительными тенденциями, рассматривалась защитниками неподвижности и неприкосновенности национальной старины как результат воздействия католического Запада, тем более, что Никон правил богослужебные книги по венецианским изданиям [Гудзий 1953, 442].

Автор исследования «Протопоп Аввакум и начало раскола», переводчик Жития на французский язык Пьер Паскаль, рассуждая о причинах раскола, видит его истоки еще в Смутном времени, в столкновении двух общественных тенденций: с одной стороны, как стремлении к власти, так и к знаниям, изучению чужеземных обычаев, а с другой, «рождается и вторая тенденция: более народная, самобытная, более специфически русская и даже провинциальная» [Паскаль 2016, 40]. Интересно, что на короткое время эти тенденции объединяются в «кружке ревнителей» под руководством Стефана Вонифатьева, однако вскоре проявляется их полярный характер: оказывается, как говорит Паскаль, что «это были два разных понимания христианства»: «Старообрядцы чувствуют, что они защищают Крест Христов против тех, кто «опустошает» его; защищают истинную религию от тех, кто хочет свести ее к минимуму. Двуперстие и вопрос о поклонах являлись лишь внешними предлогами для разрыва; двуперстие было лишь символом истинной религии. Конфликт становится неизбежным. Существуют две церкви. Естественно, что царь становится на сторону более уступчивой, архиереи повинуются ему; в 1666 году собор утверждает раскол» [Паскаль 2016, 40]. 
Главный идеолог русского старообрядчества протопоп Аввакум, как уже отмечалось, свое «Житие», а также свыше шестидесяти различных сочинений - «слова», толкования, поучения, челобитные, письма, послания, беседы - написал главным образом в Пустозерске, заточенный в земляной сруб. Почти половину своей жизни Аввакум провел в ссылках и тюрьмах, отважно борясь с церковными и светскими властями, с самим царем как за «старую веру», так и защищая простых людей. Мученик, лишенный возможности обращаться к своей пастве непосредственно впрямую в устной проповеди, взялся за перо, войдя в историю как народный заступник, символ старообрядческого движения. А.М. Панченко, обращая внимание, что при начале раскола страдальцев и борцов были многие тысячи и задаваясь вопросом, почему же именно за Аввакумом закрепилось это представление символа, почему Россия всем остальным предпочла Аввакума, отмечает:

Оттого, что он обладал замечательным даром слова и был на голову выше своих современников как проповедник, как «человек пера», как стилист. Из писателей XVII в., вообще весьма богатого литературными талантами, только Аввакуму пристал эпитет гениальный. С тех пор, как в 1861 г. Н.С. Тихонравов издал Житие Аввакума и оно вышло за пределы старообрядческого чтения, художественная сила этого шедевра была признана раз навсегда, единодушно и без колебаний [Панченко 1980, 1/391].

Самым замечательным и самым известным русским писателем XVII века называет Аввакума академик Д.С. Лихачев [Лихачев 1975, 299]. В свою очередь делится впечатлениями, произведенными на него Житием и личностью автора, П. Паскаль: «И передо мной вырисовывалась еще душа исключительного человека с глубоким чувством совести, несокрушимая вплоть до самой смерти. В нем, в этом гениальном человеке, обитала еще удивительная духовная свобода, питаемая глубокой верой в Провидение и постоянным погружением в сверхчувственный мир» [П. Паскаль 2016, с. 33].

Разумеется, в задачи авторов университетского учебника по древней белорусской литературе П.П. Ахрименко и М.Р. Ларченко не входило сравнительное исследование Диариуша Афанасия Филипповича и Жития протопопа Аввакума. Краткой концептуальной характеристикой обращалось внимание на общие тенденции в развитии родственных восточнославянских литератур, а также, что было особенно важно в советское атеистическое время, отдавалось должное прежде всего Афанасию Филипповичу, имя и творчество которого только начинало осваиваться белорусским литературно-культурным контек- 
стом в XX веке. Следует вспомнить, что настоящим событием стало возвращение в белорусскую литературу в самом конце пятидесятых годов целого ряда авторов и их произведений, а среди них как раз и Афанасия Филипповича с его Диариушем, осуществленное Александром Коршуновым. В 1959 году выходит первая в Беларуси «Хрэстаматыя па старажытнай беларускай літаратуры» [Хрэстаматыя, 1959], составленная и подготовленная на то время молодым белорусским исследователем под компетентным руководством профессора И.П. Еремина. Наконец под одной обложкой были собраны памятники древней белорусской литературы, востребованные не только студентами филологических, гуманитарных факультетов высших учебных заведений, но и научными сотрудниками, как филологами, так и историками. А. Коршунов сопроводил тексты вступительными статьями, содержащими краткую характеристику произведений, данные об авторах и их литературной деятельности ${ }^{1}$. Очевидно, что личность, творческая индивидуальность Афанасия Филипповича особенно заинтересовала А. Коршунова, о чем свидетельствует факт выхода в середине 60-х годов в академическом издательстве «Наука и техника» отдельного исследования, посвященного жизни и творчеству подвижника и его произведения [Коршунов 1965]. Таким образом, в Беларуси был актуализирован полный текст Диариуша, впервые увидевший свет в 1878 году в «Русской исторической библиотеке» (Санкт-Петербург). Издание А. Коршунова до сих пор остается востребованным исследователями белорусской мемуарной, полемической литературы. Его осмысление наследия автора Диариуша было приоритетным почти до конца прошлого века, являясь исходным пунктом для дальнейшего углубленного анализа памятника, его культурно-исторического контекста в уже новых социально-политических условиях. Так, в 2003 году в Национальной Академии Наук Беларуси состоялась защита кандидатской диссертации Ларисы Гедимин на тему «Творчество Афанасия Филип-

1 По существу, благодаря А. Коршунову увидела свет не просто хрестоматия, a, можно сказать, первая антология письменного наследия Беларуси XI-XVIII веков, содержание которой концептуально определялось двумя государственностями Беларуси - кривицкой Полоцкой и периодом Великого Княжества Литовского. Восприятие и отражение А. Коршуновым белорусского культурно-духовного пространства в границах полиэтнического Великого Княжества Литовского звучало в унисон многолетней перманентной борьбе белорусских гуманитариев-патриотов за восстановление исторической справедливости и памяти, без которой нет народа. Жанр хрестоматии обусловил хранологический, а значит, классический порядок подачи текстов, по-своему ограничивая свободу составителя, однако как раз выбором текстов и была отчетливо засвидетельствована позиция составителя «Хрестоматии..». 
повича в контексте православной полемической литературы конца XVI - первой половины XVIII вв.». Кстати напомнить, что в настоящее время существует также несколько переводов-адаптаций Диариуша на современный белорусский язык.

Диариуш представляет собой сборник разных по жанру и предназначению произведений из семнадцати частей, две из которых были написаны после смерти Афанасия Филипповича монахами берестейского Симяоновского монастыря. Текст самого автора состоит из десяти самостоятельных произведений, возникших в разное время (с 1638-го по 1646 год) и объединенных пятью вставками, которые относятся к 1646 году и выполняют информационно-композиционную роль. Очевидно, что с их помощью публічыстыцны звод атрылмаў стройнасць i лагічнасць выкладання [Коршунаў 1960, 3/143]. Взяться за перо, в современном понимании слова стать писателем, Афанасия Филипповича побудила сама общественно-политическая ситуация, а именно, как отмечает Л. Гедимин, стремление рассказать о своей борьбе от самого начала и до конца, что в итоге и определило особенности произведения. Такім чьинам, «Дьярыуш» з'яўляецча публічьлттычньм зводам, але гэта не можа быць вызначэннем жанру. Тут яскрава выявіугся сінкрэтызм $і$ сінтэтызм старабеларускай літаратурьи, дзе адны творь уваходзячь у склад другіх. Кожная з частак «Дьярыуша»адносічиа да пэўнага жанру, але ў сукупнасці янь складающь адзіны ў жанравылм плане твор [Гедзімін 2007, 1/595) Очевидно, что эта целостность, сквозная идея, повествовательная логика, обеспеченные личностной, творческой индивидуальностью автора, сигнализировали о вызревании в белорусской литературе середины XVII века новых тенденций, а именно автобиографического подхода в отображении действительности и месте конкретного человека в ней. В свою очередь исследовательница белорусской мемуаристики Алена Богдан называет автобиографически-мемуарное жизнеописание «Диариуш» этапным произведением в процессе становления и развития жанра мемуарной прозы [Богдан 2009, с. 372].

Точные биографические данные об Афанасии Филипповиче отсутствуют. Известно, что с 1620 года он работал при дворе Льва Сапеги домашним учителем Яна Фаустина Лубы, будто бы внука Ивана Грозного от его убитого в детском возрасте младшего сына Дмитрия, под именем которого в 1604-1612 годах выступали несколько самозванцев. Несомненно, сначала Афанасий Филиппович был уверен в своей воспитательной миссии, однако через некоторое время догадавшись, что занимается воспитанием не царевича, бросил службу при дворе 
и постригся в монахи виленского Святодуховского монастыря. Здесь он был возведен в сан иеромонаха и священника, а в 1633 году направлен наместником игумена в Дубойский монастырь возле Пинска, который однако в 1636 году был передан иезуитам и А. Филиппович перешел в Купятицкую обитель, где у него созрел план посетить русского царя в надежде получить подаяние на восстановление Купятицкой церкви. Около четырех месяцев длилось полное препятствий и риска путешествие А. Филипповича в Москву, где он, оказавшись в начале 1638 года, чтобы добиться аудиенции, написал специальную реляцию царю Михаилу Федоровичу, в которой объяснял цель своего визита. Эта реляция, названная впоследствии автором «История путешествия в Москву», была первым художественно-публицистическим произведением Афанасия Филипповича. Свое пребывание в Москве он обосновал как исполнение воли Пресвятой Богородицы, явившейся ему в облике ожившей купятицкой иконы во время усердной молитвы в церкви. Сообщил Филиппович царю и о подготовке илжедмитрия. 16 июля 1638 года он вернулся в Купятицкий монастырь.

Очевидно, поездка в Москву укрепила авторитет Афанасия Филипповича среди православных. В 1640 году он избирается брестскими братчиками Рождественского братства игуменом Симяоновского монастыря. В Бресте новоизбранный игумен разворачивает активную деятельность против униатской капитулы и ее экономических притязаний к православному братству. В 1641 году А. Филиппович совершает свою первую поездку в Варшаву на вальный сейм, чтобы защитить интересы братства и укрепить материальную базу Симяоновского монастыря.

Король Владислав IV Ваза благосклонно отнесся к Афанасию Филипповичу, засвидетельствовав предъявленные игуменом копии документов, он выдал свой привилей, согласно которому брестскому Рождественскому братству гарантировались юридические права, более того, разрешалось приобрести в городе участок под застройку его братской школой и домом. Однако канцлер Радзивил и подканцлер Тризна отказались признать привилей, заявив, что это возможно лишь при условии, что сам игумен и его послушники примут церковную унию. Продолжая борьбу, в 1643 году Афанасий Филиппович опять отправляется в Варшаву с намерением обличить на вальном сейме противозаконные действия властей, ущемляющих интересы православных и надеясь на поддержку короля и некоторых сенаторов. Для большей убедительности он подготовил семь копий своей «Истории путешествия в Москву» и к каждой копии приложил по экземпляру типографских оттисков иконы Купятицкой Богоматери. В удобный момент с позволения мар- 
шалка Опалинского и познанского епископа Шолдровского он появился на одном из заседаний сейма и роздал подготовленные «свитки», а потом с сеймовой трибуны выступил с «Супликой», адресованной королю Владиславу, жалуясь на самоуправство канцлера и подканцлера и требуя от короля быстрейшего упразднения унии, в противном случае обещая схождение гнева божьего. За это выступление Афанасия Филипповича обвинили в нарушении сеймовых традиций и подвергли аресту. Казалось бы, исчерпав возможности в борьбе за справедливое решение насущных проблем, в какой-то момент он вырывается из заточения и, выдавая себя за юродивого, бегает раздетый по улицах Варшавы:

ревностю дому Божого запалишися и собою взгордивши, не будучи шаленым и овшем маючи имя Исус Христово на сердцу моем выритое, толко для самого упаметаняся старших отцев моих, доброволне, не жалуючи себе и в болоте ся помазати, абы церков, облюбеница Христова, одета и очищена была, щалемным як бы учинившися, из везеня сам вчесне вышедши наго, толко каптур и парамант для знаку законого на собе маючи, в болоте ввесь поплюскавшися и костуром себе бьючи, по улицах варшавских бегал и волал великим голосом: «Беда проклятым и неверным! Беда проклятым и неверным! Vae malediktus et infidelibus!» Што постерегши в господи, челядь владычая след пошляковали и бегучого мене юж до брами краковское (бо хотелем в рынку в костелы вбегати и волати тые ж слова, - а то в день Звестованя, - по-новому: «Беда, беда проклятым и неверным!») там теды под брамою мя обскочили и, потрутивши в болото, в колено и болш глубокое, стали надо мною з великим тумултом людей през долгий час, аж з господы воз привезено [Филиппович 2003, 786-787], -

так описывает автор «Диариуша» этот свой поступок в наибольшей по объему и важнейшей части произведения «Новинах правоверным пожаданых о успокоении веры и церкви православной восточной, як бы супликуючи през них до кроля пана и до сенату его всего, ведлуг титулов каждого». Обращаясь непосредственно к королю Речи Посполитой, в этой части Диариуша Афанасий Филиппович наиболее последовательно излагает факты своей биографии, описывает критическое состояние православия в стране, которое он видит худшим, чем нахождение под турками, высказывает разочарование в высшем православном духовенстве, принявшем унию, как и остальные полемисты того времени, выступает против «латинской мудрости» и т.д. Очевидно, как отмечает Л. Гедимин: «Навіньл...» Афанасія Філіповіча - гэта твор, у якім найбольш ярка раскрьваечиа палемічная скіраванасщь «Дьярыуша»: для дасягнення палемічных мэтаў ауттар карыстаециа разнастайнь- 
мі сродкамі і ўздымае найбольш злабадзённую для праваслайных пісьменнікаў тэматыку [Гедзімін 2007, 604].

Первая автобиография в древней русской литературе, которую представляет собой Житие протопопа Аввакума, им самим написанное, дошла до нашего времени в трех редакциях, явившись наиболее полным и достоверным источником многострадальной жизни автора, его борьбы за «старый обряд», «за истинную веру»². Д. Лихачев отмечает, что стилистическая манера Аввакума неразрывно связана с крайне мучительными обстоятельствами его жизни, в которых создавались его сочинения: Перед лиџом мученичества и смерти он чужд лжи, притворства, лукавства. «Прости, Михайлович-свет, - писал он иарю, - любо потом умру, да же бы тебе ведомо было, да никак не лгу, ниж притворяяся, говорю: в темниче мне, яко во гробу, что надобна? Разве смерть! Ей, тако», «Ей, не лгу», «невозможно богу солгати» - такими страстными заверениями в правдивости своих слов полны его писания [Лихачев 1975, с. 300].

Таким образом, предельно искренне, откровенно, не избегая конкретных подробностей, Аввакум рассказывает о себе с детства до ссылки в Пустозерск, подчеркивая, что его отец священник любил $n u-$ тие хмельное, а вот мать была постница и молитвеннича, принявшая во вдовстве монашество. Аз же пресвятей Богородице молихся, да даст ми жену помошнииу ко спасению. И в том же селе девица, сиротина ж, безпрестанно обыкла ходить во иерковь, - имя ей Анастасия [Житие протопопа Аввакума 1969, 630], которая мужественно сопровождала Аввакума во всех его испытаниях, а в Пустозерске наряду с Аввакумом отбывала наказание в земляной темнице вместе с сыновьями Иваном и Прокопием. В двадцать один год Аввакум был рукоположен в дьяконы, еще через два года - в священники, спустя же восемь лет стал протопопом. A егда в попах был, тогда имел у себя детей духовных много, - по се время сот с пять или с шесть будет. Не почивая, аз, грешньй, прилежал во черквах, и в домех, и на распутиях, по градом и селам, еще же и в иарствующем граде, и во стране Сибиръской проповедуя и уча слову божию, - годов будет тому с полтретьячеть [Житие протопопа Аввакума 1969, 631], - вспоминает Аввакум. Одиннадцать лет вместе с семьей скитался Ав-

2 На польском языке Житие увидело свет в начале 70-х годов: Żywot protopopa Awakuma przez niego samego nakreślony i wybór innych pism, przełożył oraz wstępem i komentarzem opatrzył Wiktor Jakubowski, Wrocław - Warszawa - Kraków - Gdańsk, Zakład Narodowy imienia Ossolińskich, Wydawnictwo Polskiej Akademii Nauk 1972. 
вакум в тяжелейших условиях по Сибири, куда был сослан за свое активное сопротивление никоновской реформе.

$\mathrm{C}$ традиционной точки зрения объединение автора и героя агиографического повествования в одном лице в тогдашней литературе было недопустимо. Аввакум это, конечно, осознавал сам, потому и начинает свое Житие со своеобразного вступления-оправдания: Аввакум протопоп понужен бысть житие свое написати иноком Епифанием, - понеж отеи ему духовной инок, - да не забвению предано будет дело божие; сего ради понужен бысть отцем духовным на славу Христу богу нашему. Аминь (Житие протопопа Аввакума 1969, 626). Далее же, оставаясь верным христианской традиции начинать каждое дело с молитвы, Аввакум обращается к Пресвятой Троице с просьбою о содействии его начинанию. И, несомненно, что он чувствовал свое право, а также и моральную обязанность успеть поделиться пережитым во имя наставления, духовного укрепления сподвижников по праведной, по его убеждениям, борьбе.

Конечно, заключение Брестской церковной унии по значимости предполагаемых изменений в статусе православия в Речи Посполитой представляло собой действительный социальный катаклизм, что как раз и нашло, в частности, отражение в Диариуше. В то время как никоновская реформа имела ввиду изменения, казалось бы, локального характера, не затрагивающие сущностных основ, однако протестная реакция на нее охватила широкие круги населения и вошла в историю России как глубоко драматическое движение, оставаясь актуальным на протяжении длительного времени и влияя на дальнейшую судьбу православия и духовной жизни в России. Так, П. Паскаль, вероятно, не без оснований замечает, что Петр I видел в староверах главную помеху своему главному замьлслу: секуляризации Русского государства наподобие протестанской Европь [Паскаль 2015, 616].

Несомненно, в Диариуше Афанасия Филипповича и Житии протопопа Аввакума нашли отражение новые в отличие от средневековой культуры принципы самосознания личности, оригинальные способы их выражения, предопределенные главным образом, как уже отмечалось, яркой индивидуальностью авторов, их верностью данным от рождения внешним и внутренним приоритетам, а вследствие этого деятельным участием в типологически близких по своей внутренней сущности событиях. Востребованность же современностью сочинений белорусского и русского подвижников XVII века свидетельствует о непреходящем значении их трагического опыта борьбы за свои убеждения, высоком духовном потенциале Диариуиа и Жития. 


\section{Литература}

Ahrymenka P.P., Larčanka M.R., Staražytnâ̂a belaruskâ̂ litaratura, Mìnsk 1968 [Ахрыменка П.П., Ларчанка М.Р., Старажытная беларуская літаратура, Мінск 1968].

Bogdan A.Ì., "Dyâryuš" Afanasîa Filipoviča âk memuarny žyccâpis, (u:) XIV Meždunarodnye Kirillo-Mefodievskie čteniâ, posvâ̂̂ennye dnâm slavânskoj pis'mennosti i kul'tury (Minsk, 22-24 mâ̂ 2008), Mefodievskie čteniâa, posvâŝennye dnâm slavânskoj pis'mennosti i kul'tury (Minsk, 22-24 mâ̂ 2008), Minsk 2009 [Богдан A.I., “Дьярыуш" Афанасія Філіповіча як мемуарны жыцияпіс, (у:) ХІV Международнье Кирилло-Мефодиевские чтения, посвяшенные дням славянской письменности и культуры (Минск, 22-24 мая 2008), Минск 2009].

Gedzìmìn L., Afanasij Filipovič, (u:) Gistoryâ belaruskaj litaratury XI-XIX stagoddzâǔ. U dvuh tamah, Minsk 2007, t. 1 [Гедзімін Л., Афанасій Філіповіч, (у:) Гісторыля беларускай літаратуры XI-XIX стагоддзяў. У двух тамах, Мінск 2007, т. 1].

Gryckevì̌, Brèsckâ̂ unîa 1596, (u:) Èncyklapedyâ gistoryi Belarusì. U 6 tamah, Mìnsk 1994, t. 2 [Грыцкевіч, Брэсцкая унія 1596, (у:) Энцыклапедыля гісторыі Беларусі. У 6 тамах, Мінск 1994, т. 2].

Gudzij N.K., Istoriâ drevnej russkoj literatury, Moskva 1953 [Гудзий Н.К., История древней русской литературь, Москва 1953].

Brestskâ̂ uniâ $1596 \mathrm{~g}$. i obŝsestvenno-političeskâ̂ bor'ba na Ukraine $i$ v Belorussii $v$ konce XVI - načale XVII v. Čast' I. Brestskâ̂ uniâ $1596 \mathrm{~g}$. Istoričeskie pričiny, Moskva 1996 [Брестская уния 1596 г. и общественно-политическая борьба на Украине и в Белоруссии в конце XVI-начале XVII в. Часть І. Брестская уния 1596 г. Исторические причины, Москва 1996].

Koršunaǔ A.F., Da pytannâa ab žanry i kampazicyi "Dyâryuša”, (u:) Belaruskâ̂ litaratura. Dasledavanni i publikacyi, Mìnsk 1960, t. 3 [Коршунаў А.Ф., Да пьттання аб жанры і кампазіцыі “Дьярыуша", (у:) Беларуская літаратура. Даследаваннні і публікаџыл, Мінск 1960, т. 3].

Koršunov A.F., Afanasij Filippovič. Žizn' i tvorčestvo, Minsk 1965 [Коршyнов А.Ф., АФанасий Филиппович. Жизнь и творчество, Минск 1965].

Kuncèvič Âsafat, List da L'va Sapegì, (u:) Antalogîa daǔnâj belaruskaj litaratury.

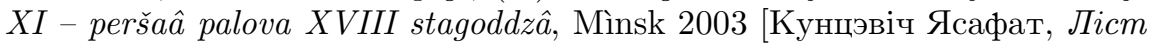
да Льва Сапегі, (у:) Анталогія даўняй беларускай літаратурь. XI першая палова XVIII стагоддзя, Мінск 2003].

Žitie protopopa Avvakuma, (v:) «Izbornik». Sbornik proizvedenij literatury Drevnej Rusi, Moskva 1969 [Житие nротопопа Аввакума, (в:) «Изборник». Сборник произведений литературь Древней Руси, Москва 1969].

Lihačev D.S., Velikoe nasledie. Klassičeskie proizvedeniâ literatury Drevnej Rusi, Moskva 1975 [Лихачев Д.С., Великое наследие. Классические произведения литературь Древней Руси, Москва 1975]. 
Mâkotin V.A., Protopop Avvakum. Ego žizn' i deâtel'nost', Moskva 2002 [Мякотин В.А., Протопоп Аввакум. Его жизнь и деятельность, Москва 2002].

Padokšyn S.A., Unî̂. Dzâržaŭnasc'. Kul'tura (Filasofska-gistaryčny analiz), Mìnsk 2000 [Падокшын С.А., Унія. Дзяржаўнасць. Культура (Філасофска-гістарычны аналіз), Мінск 2000].

Pančenko A.M., Literatura «perehodnogo veka», (v:) Istoriâ russkoj literatury. $V$ 4-h tomah, Drevnerusskâa literatura. Literatura XVIII veka, Leningrad 1980, t. 1 [Панченко А.М., Литература «переходного века», (в:) История русской литературы. В 4-х томах, Древнерусская литература. Литература XVIII века, Ленинград 1980, т. 1].

Paskal' P., Avvakum i načalo raskola, 2-e izd., ispravlennoe, Moskva 2016 [Паскаль П., Аввакум и начало раскола, 2-е изд., исправленное, Москва 2016].

Sapega L., List da Âsafata Kuncèviča, (u:) Antalogîa daŭnâj belaruskaj litaratury. XI - peršâ̂a palova XVIII stagoddza, Minsk 2003 [Сапега Л., Лicm дa Ясафата Кунчэвіча, (у:) Анталогія дайняй беларускай літаратуры. XI - периая палова XVIII стагоддзя, Мінск 2003].

Saverčanka İ., Palemičnâ̂ litaratura, (u:) Gistoryâ belaruskaj litaratury XI-XIX stagoddzâŭ. U dvuh tamah, Mìnsk 2007, t. 1 [Саверчанка I., Палемічная літаратура, (у:) Гісторыля беларускай літаратуры XI-XIX стагоддзяў. У двух тамах, Мінск 2007, т. 1].

Fìlìpovič A., Dyâryuš, (u:) Antalogiâ daŭnâj belaruskaj litaratury. XI - peršaâ palova XVIII stagoddzia, Minsk 2003 [Філіповіч А., Дьиярыучи, (у:) Анталогія даўняй беларускай літаратуры. XI - першая палова XVIII стагоддзя, Мінск 2003].

Hrèstamatyâ pa staražytnaj belaruskaj litaratury, sklaǔ A.F. Koršunaǔ, Mìnsk 1959 [Хрэстаматыя па старажытнай беларускай літаратуры, склаў А.Ф. Коршунаў, Мінск 1959].

Żywot protopopa Awakuma przez niego samego nakreślony i wybór innych pism, przełożył oraz wstępem i komentarzem opatrzył Wiktor Jakubowski, Wrocław - Warszawa - Kraków - Gdańsk, Zakład Narodowy imienia Ossolińskich, Wydawnictwo Polskiej Akademii Nauk 1972.

\title{
AFANASIJ FILIPOVICH'S "DIARIUŠ" AND PROTOPOP AVVAKUM'S "ŽITIE": TYPOLOGICAL SIMILARITIES IN THE HISTORICAL CONTEXT
}

\author{
ABSTRACT
}

A leading position in the 17th century Belarusian literature is occupied by Afanasij Filipovich, a writer and publicist, a political and Orthodox Church activist. His "Diariuš", an autobiographical work is one of the most distinctive examples of polemic publicity devoted to the fight against the Brest Union in 1596 and its tragic consequences. 
Meanwhile, a special place in the 17th century Russian literature is occupied by protopop Avvakum's "Žitie" - a remarkable first apostle and a symbol of the Old Believers movement whose life experience served as the first autobiography in Russian literature.

Afanasij Filipovich's "Diariuš" and protopop Avvakum's "Žitie" present sufficient grounds for considering various typological similarities and parallels in authors' fate and the pathos of their works. New principles of the selfawareness of an individual and the ways of expressing them are present in the works of Belarusian and Russian writers.

Key words: polemic literature, autobiography, autobiographism, the pathos of the work, spiritual potential, the Brest Union, the Old Believers movement 